\title{
ANALYZING THE BARRIERS OF PAK-INDIA TRADE ON TEXTILE EXPORTS BY USING CGE MODEL
}

Faiz Muhammad Shaikh

Assistant Professor

SZABAC-Dokri-Larkana-Sindh

Pakistan

Email:faizanmy2000@hotmail.com

Dr. Abdullah Sethar,

D.V.M., M. Sc (Honors) from Pakistan

and Ph.D from England, UK.Deputy Project Director,

Sindh Agricultural Growth Project ( Livestock Component)

World Bank Assisted, Government of Sindh,

Hyderabad-Sindh

Prof. Fayyaz Mahmood

Saudi Industrial Development Fund,

Ministry of Petroleum,

Industries, and mining, Riyadh, Saudi Arabia.

Dr.Muhammd Ali Bhatti

Assistant Professor

IBA-Sukkur

Abstract:This research investigates the analyzing the barriers of Pak-india trade on textile exports by using CGE model. Data were collected from 50 exporters by using simple random technique. Data were analyzed by using SPSS-21version, A structural questionnaire was developed for the reliability and validity of the data. It was revealed that Exporters'opiniononexportafterdecreasingthestrengthofbarriersExporters have been askedif they are ready toexport moretothe INDIAafter these barrierswillbeless,and70\% of theexporterssaidyes, $22 \%$ saidmaybe, and $8 \%$ said

no. Thus, exportersarepositiveregardingexporttotheINDIA.India'sexporttotheINDIAcan be increased if these barriers get less or are removed. It was further revealed that

Accordingly,theresultssuggestthatareductionofimporttariffsto10percentwillincreasePakistan's welfareandterms-of-

tradeaswell.Althoughonemightexpectthatthereductionofimporttariffswouldincreasethedomesti coutputandthereforeincreaseexportsales, thispolicy reformwouldadverselyaffectPakistan's domesticoutputinmostofthesectorsbecauseofforeign competition.Asimilar impactcanbeseeninexportsalestoo

Key Words-ISSUES, PAK-INDIA, TRADE

\section{Introduction}

Textile industry of Pakistan is broadly divided into many sectors that are Ginning, Spinning, Weaving, Knitting, Towel, Dying, Printing, Processing, Hosiery, Made-ups and Garments. As the first objective is concerned with understanding the current status of textile industry; in this connection a survey of the entire textile industry will be conducted. A total of 48 companies were be selected for conducting the research in Hyderabad, Kotri, Karachi, Faisalabad and Lahore region including the key integrated textile units to ensure full representation of all sectors. Further the above sectors of textile industry were lumped together into four major sectors as Spinning, Weaving (including Knitting, Dying \& Printing (including Processing and Bleaching), and Garments (including Made-ups, towel, Hosiery and other manufactured items) for compiling the qualitative information. The survey methodology included a combination of primary data that was generated through a questionnaire and intensive interviews with individuals connected to the industry to identify 
International Journal of Management and Information Technology

their internal issues, national issues, global issues and required remedial actions and the secondary data included journal articles, trade policies of Pakistan, news, and internet which were helpful for the second and the third objectives. In the second objective the graphs are used to explain the growth pattern of textile exports from the year 1980 to 2009 as the implementation of WTO on textile industry of Pakistan started from 1995 that was 100\% complete in 2005. Therefore the starting 14 years from 1980 to 1994 are considered as the time period with quotas, whereas the last 14 years from 1995 to 2009 are considered as the quota free era. In the third objective developing countries like China, India, Srilanka and Bangladesh are taken into account to analyze the effects of WTO on them. Here the information collected through the above mentioned secondary sources regarding the benefits of becoming the member of WTO and the problems associated with its implementation are highlighted.

\section{The Textile Industry of Pakistan}

One of the major economic indicators for the development of Pakistan economy is textile Industry. Textile Industry is an important source of the overall and major export of the country. In fact, Pakistan is ranked in top most leading cotton producing countries of the world. Statistically, till 1997 Pakistan was named as world's largest exporter of yarn. In 1999, it was ranked on the second position in the largest exporter of textile made-ups list. In textile made-ups sources, the second largest sources were the bed wear and linens sub sectors. These both shared about 28 per cent share of total textile made-ups in 1999 (SMEDA, 2002). In addition, Pakistan became second largest exporter of bed wear and linen globally during that period. i

\section{DATA COLLECTION METHODOLOGY}

Data were collected from 50 exporters by using simple random technique. Data were analyzed by using SPSS-21version, A structural questionnaire was developed for the reliability and validity of the data.

Table6.1:Experiment-1-15PercentUniformImportTariffsEstimated Welfare and Trade Effects (Percentage changes in millions)

\begin{tabular}{|l|l|l|l|l|l|l|l|l|}
\hline Countries & EV US $\$$ & \% of GDP & TOT & V-Export & V-Import & Exp-Price & Import-Price & $\begin{array}{l}\text { DTBAL- } \\
\text { Price }\end{array}$ \\
\hline IND & $\mathbf{3 2 1 3 . 9 7}$ & $\mathbf{3 . 4 0}$ & $\mathbf{0 . 4 1}$ & $\mathbf{0 . 4}$ & $\mathbf{1 . 2 3}$ & $\mathbf{2 . 1}$ & $\mathbf{3 . 6 8}$ & $\mathbf{1 0 9 . 7 4} \mathbf{m}$ \\
\hline PAK & $\mathbf{4 4 4 2 . 6 3}$ & $\mathbf{4 . 3 5}$ & $\mathbf{5 . 9 8}$ & $\mathbf{2 . 1 9}$ & $\mathbf{0 . 6 1}$ & -8.97 & $\mathbf{5 . 4 4}$ & $\mathbf{2 8 5 . 6 6 m}$ \\
\hline XSA & -1592.56 & -1.74 & -0.57 & -3.92 & 31.54 & 24.83 & -2.12 & $-1322.73 \mathrm{~m}$ \\
\hline XWA & -375.79 & -0.02 & 0.00 & -0.04 & 0.00 & -0.06 & -0.05 & $149.69 \mathrm{~m}$ \\
\hline
\end{tabular}




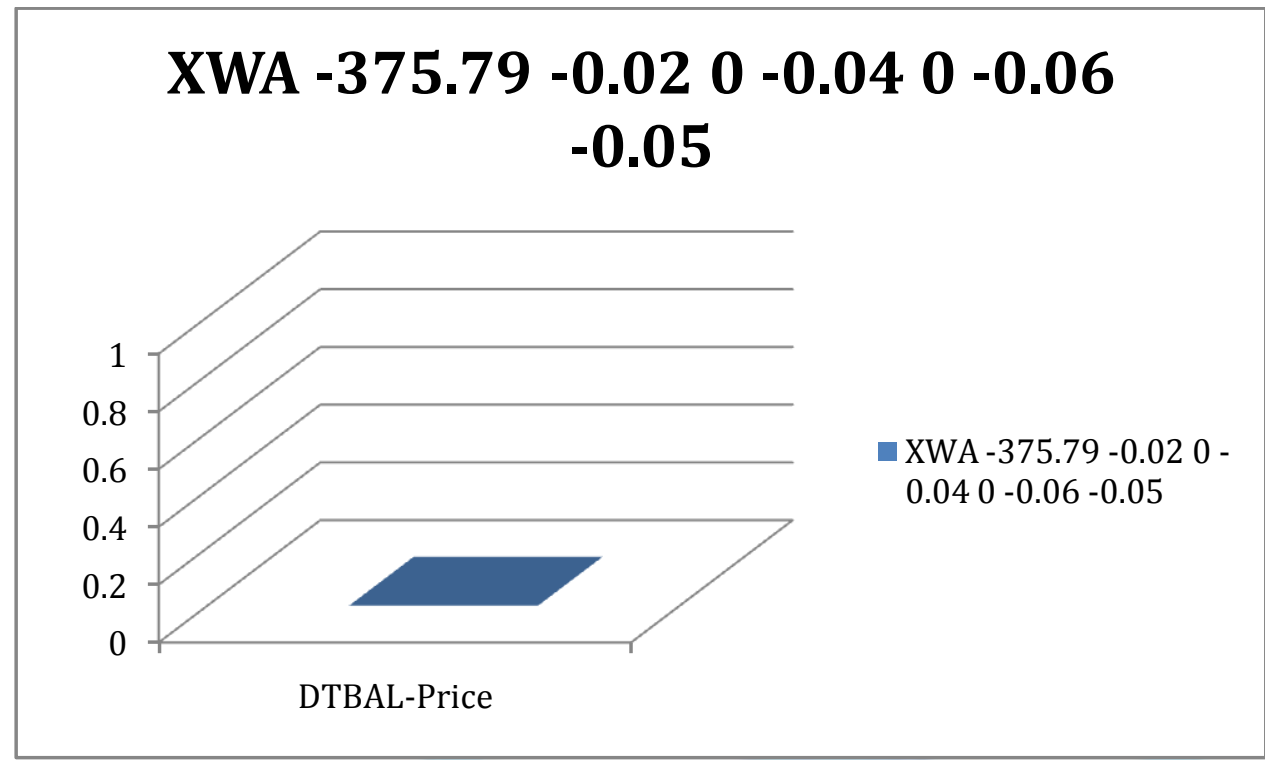

Description

IND=INDIA

PAK=PAKISTAN

$X S A=$ REST OF SOUTH ASIA

$X W A=$ REST OF WORLS

All experiments were conducted with the standard general equilibrium closure of the GTAP model. According to the results Base line tariff for India is $18 \%$ SAFTA tariff is $5 \%$ and given MFN Tariff is $15 \%$ and rest of world is $15 \%$.. The first experiment considered the Pakistan's reduction of import tariffs to 15 percent under the unilateral trade liberalization. The impact of this scenario on regional welfare and the resulting percentage changes in sectoral output and trade are reported in Table 6.1 Accordingly, if Pakistan (PAK) reduces its import tariffs to 15 percent unilaterally on a global basis to maintain a uniform external tariff rate, Pakistan's EV US\& 4442.63 and GDP 4.35, and India's EV US\$ 321 million (3.40 percent of the GDP). Under this scenario, Pakistan's volume of imports rises by 1.23 percent while its volume of exports falls slightly by 0.4 percent reflecting the fact that the pressure to increase imports is stronger than the increase in demand for Pakistan's exports by unilateral liberalization. However, as a result of the composite export price increase by 2.1 percent, Pakistan's experiences a small improvement in the terms-of-trade of 1.5 percent and the real GDP by 0.9 percent. The welfare gains or losses for other regions are quite varied under this simulation. However, since Pakistanis impact on unilateral reduction of import tariffs to 15 percent will not affect other region's real GDP or terms-of-trade significantly. 
Table6.2:Experiment115PercentUniformImportTariffsEstimatedPercentageChangesinRegionalOutputandTrade Sector

IND

PAK

XSA XWA

(a)IndustryOutput (In Millions)

\begin{tabular}{|l|l|l|l|l|}
\hline TEXT & $\mathbf{1 . 4 5 . 0 3}$ & $\mathbf{2 . 6 0}$ & 0.01 & 0.11 \\
\hline & & & & \\
\hline & \multicolumn{5}{|l|}{} \\
\hline & \multicolumn{5}{|l|}{} & & \\
\hline & & & & \\
\hline & & & &
\end{tabular}

\begin{tabular}{|l|l|l|l|l|}
\hline TिEXT & -0.16 & 6.79 & 0.01 & 0.11 \\
\hline & & & & \\
\hline & & & & \\
\hline
\end{tabular}

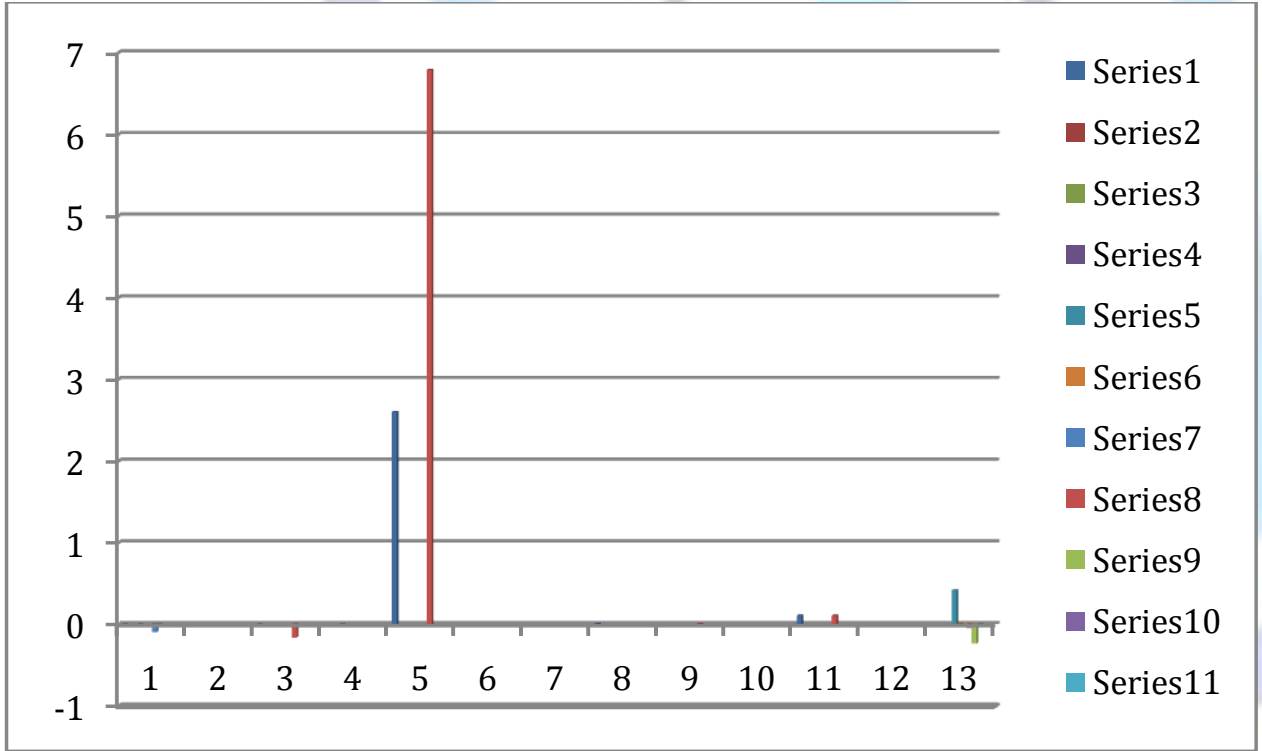

Tariff Rates

$5 \%$ SAFTA

$15 \%$ XWA

$5 \%$ XSA

15 MFN 
Table6.2:Experiment-2SouthAsianFreeTradeAgreement-SAFTA- EstimatedWelfare and Trade Effect

\begin{tabular}{|c|c|c|c|c|c|c|c|c|}
\hline Countries & EV US\$ & $\%$ Of GDP & TOT & Vole-Export & Volume-Import & $\begin{array}{l}\text { Export } \\
\text { Price }\end{array}$ & $\begin{array}{l}\text { Import- } \\
\text { Price }\end{array}$ & $\begin{array}{l}\text { DTBAL } \\
\text { US\$ }\end{array}$ \\
\hline IND & 5434.97 & 4.34 & 0.80 & 5.40 & 4.00 & 9.38 & 8.68 & 1100.9 \\
\hline PAK & 5643.63 & 6.35 & 0.99 & 7.11 & 7.77 & 5.97 & 7.44 & $\overline{786.77}$ \\
\hline RAS & -1592.56 & -1.74 & -0.57 & -3.92 & 31.54 & 24.83 & -2.12 & 1322.7 \\
\hline
\end{tabular}

Tariff Rates

$\mathrm{SAFTA}=5 \%$

$\mathrm{MFN}=10 \%$

$\mathrm{XWA}=10 \%$

SAFTA $=10$

The trade reform scenario (Experiment-2) was conducted under the regional trade liberalization policy option to examine the impact of South Asian Free Trade AgreementSAFTA in different contexts from the perspective of Pakistan. As a member of the SAFTA, Pakistan. committed to continue major trade liberalization measures, to establish and promote free trade arrangements for strengthening inter-regional economic co-operation and the development of national economies. In this experiment, it was assumed that Pakistan and each of the SAARC member countries in the model (India and the Rest of South Asia comprising Bangladesh, Bhutan, Maldives, Nepal and Sri lanka) remove their tariffs against each other, while maintaining heir tariffs against the rest of the South Asia.

Table6.3:Experiment-2

\section{PercentUniformlmportTariffs}

\section{EstimatedPercentageChangesinRegionalOutputandTrade}

Sector

IND

PAK

XSA

XWA

(a) IndustryOutput

\begin{tabular}{|l|l|l|l|l|}
\hline TEXT & $\mathbf{0 . 0 3}$ & $\mathbf{0 . 6 0}$ & 0.01 & 0.11 \\
\hline & & & & \\
\hline & & & & \\
\hline Exports & & & & \\
\hline TEXT & $\mathbf{0 . 1 6}$ & $\mathbf{8 . 7 9}$ & 0.01 & 0.11 \\
\hline
\end{tabular}

Tariff Rates

SAFTA $=5 \%$

$\mathrm{MFN}=10 \%$

$X W A=10 \%$

SAFTA $=10$

The trade reform scenario (Experiment-2) was conducted under the regional trade liberalization policy option to examine the impact of South Asian Free Trade Agreement- SAFTA in different contexts from the perspective of Pakistan. As a member of the SAFTA, Pakistan. 
committed to continue major trade liberalization measures, to establish and promote free trad arrangements for strengthening inter-regional economic co-operation and the development of national economies. In this experiment, it was assumed that Pakistan and each of the SAARC member countries in the model (India and the Rest of South Asia comprising Bangladesh, Bhutan, Maldives, Nepal and Sri lanka) remove their tariffs against each other, while maintaining heir tariffs against the rest of the South Asia. According to results in SAFTA 5\% tariff the Pakistan industry output .079 compare to India -0.4 that Pakistan's will benefit on SAFTA trade with India. Indian industry out put show s that in Auto, Textile India's position is better in compare with Pakistan.TheSecond experimentconsideredthat

Pakistan's reductionofimporttariffsto10percentundertheunilateraltradeliberalization. Theimpactofthisscenarioonre gionalwelfareandtheresultingpercentagechanges insectorialoutputandtradearereportedinTable6.1, 6.2.and6.3 reducesitsimporttariffsto10percentunilaterallyonaglobal respectively.Accordingly,ifPakistan basistomaintainauniformexternaltariffrate,Pakistan'sexperiences awelfaregainaroundUS\$201million(1.53percentoftheGDP).Underthisscenario,Pakistan's volumeofimportsrises

by3.3percentwhileitsvolumeofexportsfallsslightlyby0.3percentreflectingthefactthatthe pressuretoincreaseimportsisstrongerthantheincreaseindemandforPakistan's liberalization.However,asaresultofthecompositeexportpriceincreaseby 1.1 experiencesasmallimprovementintheterms-of-tradeof 1.5percentandtherealGDP by 0.8 percent. Thewelfaregains orlossesforother variedunderthissimulation. However, theimpactofPakistan's unilateralreductionofimporttariffsto10percentwillnotaffectotherregion'sealGDPorterms-oftradesignificantly

Accordingly,theresultssuggestthatareductionofimporttariffsto10percentwillincreasePakistan's welfareandterms-oftradeaswell.Althoughonemightexpectthatthereductionofimporttariffswouldincreasethedomesticoutputandtheref oreincreaseexportsales,thispolicy reformwouldadverselyaffectPakistan's domesticoutputinmostofthesectorsbecauseofforeign competition.Asimilar impactcanbeseeninexportsalestoo.

\section{Table6.4:SouthAsianFreeTradeAgreement-SAFTA(continued) EstimatedPercentageChangesinRegionalOutputandTrade}

\section{AggregateExports}

\begin{tabular}{|ll|ccc|} 
Sector & PAK & IND & XSA & XWA \\
\hline TEXT & -0.078 & -5.60 & 0.06 & 0.45 \\
\hline
\end{tabular}

\section{Aggregate Imports}

\begin{tabular}{|l|l|l|l|l|}
\hline TEXT & -0.76 & -5.60 & 0.03 & 0.45 \\
\hline & & & & \\
\hline
\end{tabular}

\section{Experiments-Sensitivity of the Results}

As portrayed already, to measure the effect of Trade strategy changes on Pakistan's Trade with India, three extra investigations were attempted with an expanded versatility esteem for the import-import substitution parameter (Armington parameter)- ESUBM, to consider as Pakistan-India Trade connection. As needs be, under these three trials, to start with, the span of the ESUBM expanded by 50 percent, and after that multiplied the worth (100 percent expansion) to decrease Pakistan's business sector power on the planet market. This would give a chance to look at the affectability or power of the model forecasts regarding the adjustment in the fundamental parameters.

Table .6.3 introduces the consequences of these three investigations with the focal versatility esteem situations. In this manner, under the 15 percent uniform outer tax situation (E-4), in the event that we lessens Pakistan's business sector power by expanding the estimation of ESUBM by 50 percent (E$4.1)$, it would build welfare pick up around US $\$ 201.84$ million (0.60 percent of the GDP). Thus, multiplying the worth (100\%) of ESUBM (E-4.2) would expand Pakistan's welfare by around US $\$ 237.60$ million (or 2.41 percent of the GDP). In the previous case, the increment in welfare from 
the focal worth is 0.44 percent, and in the last case, it is around 0.47 percent. In spite of the fact that these progressions are moderately little, it would recommend that even as a major nation would be in a position to pick up from the one-sided Trade liberalization. The welfare increments for the nation as the flexibilities increment. On the other hand, under these two situations, we little increment as far as Trade as flexibilities increments. Besides, under these situations, the effect on terms-of-Trade is very little unique in relation to the focal situation case

Essentially, test 2 (E-2) manages the SAFTA situation. As appeared in Table17, with the esteem's increment of ESUBM, both the welfare and the terms-of-Trade will increment straightly from the focal situation case. Subsequently, the welfare pick up for Pakistan's under the 50 percent expansion in ESUBM (E-5.1) is roughly US $\$ 33.38$ million (2.58 percent of the GDP), though under the 100 percent expansion situation (E-5.2), it is around US $\$ 422$ million (2.33 percent of the GDP). Along these lines the welfare will increment by 4.2 percent from its focal quality situation, and in the last case it will increment by 5.2 percent. Along these lines, welfare increments as versatilities increment. Along these lines, the additions are fairly direct with both the cases mirroring the model's power results.

Test 3 (E-3) considered the consolidated arrangement of SAFTA cum 15\% uniform import levies situation Thus, half increment of the estimation of ESUBM (E-6.1), would expand welfare pick up around US\$311million (from US\$221 million at the focal situation) or 5.11percent of the GDP. Here, the increment in welfare from the focal worth is 31 percent. Essentially, multiplying the estimation of ESUBM (E-6.2) would expand Pakistan's welfare by around US $\$ 720$ million or 7.22 percent of the GDP. For this situation, the increment in welfare from the focal quality is 61 percent. Additionally, under these two situations, the increment as far as Trade is 8.0 and 8.8 individually. Accordingly the changes in the terms of Trade from the focal worth are 1.7 and 3.6 percent separately. In spite of the fact that these welfare and terms-of-Trade increases are not directly identified with the adjustments in the Armington versatility ESUBM, the outcome would propose that one-sided Trade liberalization in blend with territorial Trade liberalization licenses Pakistan to grow its fare segments while all segments contend all the more nearly with a bigger number of contending mixed bags from abroad.

Table 6.3. Highlights Pakistan's sectorial yield, fares and imports under the affectability examination situations. Appropriately, Pakistan's industry yield falls altogether in all most every one of the divisions aside from critical increments in Agriculture and Textile wearing attire. Pakistan's fare additionally diminish extensively under every one of the examinations as appeared in of Table 6.4 , aside from Textile and farming under E-2, and E-3 Auto Parts, under E-6 Parma, and Financial Services and Insurance and Transport and Logistics. India's position in E-2 and E-3 vastly improved contrast with Pakistan.

\section{Non-Economic Benefits}

Other than the welfare and terms of Trade additions recommended by the reenactments, provincial Trade liberalization under SAFTA may have some non-financial advantages to Pakistan especially social and political advantages; those are hard to represent quantity. For instance, SAFTA can help its individuals to talk with one voice in worldwide arrangements and build up a typical comprehension on a few worldwide Trade related issues. It could likewise decrease the political question among individuals and make the locale a more appealing area for outside direct ventures. Pakistan is essential for getting noteworthy advantages from FDI, liberalization of Trade and FDI approaches should be supplemented by fitting arrangement measures regarding training, R\&D, and human capital aggregation if Trade transaction with India will restore.

\subsection{ISSUES ON SAFTA OF TEXTILE INDUSTRY OF PAKISTAN}

The Cronbach alpha test was applied for reliability and internal consistency of the multiitembarrierscaleonallbarriers. Theinternalconsistencyofthequestionnairewas checked by this test.

Table6.5. ReliabilityStatistics

\begin{tabular}{|l|l|l|}
\hline Cronbach'salpha & Cronbach'salphabasedonstandardizedite & Nofitems \\
\hline .987 & .988 & 25 \\
\hline
\end{tabular}

FromTable6.5 one can see that the Cronbachalpha value is 0.98 which is considered to have a very high internal consistency and reliability. So,it was concluded that the scales for the multi- item barrier questions were very reliable and had an internal consistency 


\subsection{Exporters'perceptionofbarriersduringexport/Natureofproblemfaced byPakistaniexportersduringexporttotheINDIA}

One-samplet-test

\begin{tabular}{|c|c|c|c|c|c|c|}
\hline Barrier & $\mathrm{N}$ & Mean & $\begin{array}{l}\text { Std. } \\
\text { deviatio }\end{array}$ & t-value & & Sig.at \\
\hline Tariff barrier & 50 & 3.0667 & 1.19131 & 7.196 & .000 & YeS \\
\hline governmentalregulations & 50 & 3.4667 & 1.25505 & 9.299 & .000 & YeS \\
\hline Priceofthecommodity & 50 & 2.5833 & 1.12433 & 4.294 & .000 & YeS \\
\hline Marketaccessproblem & 50 & 3.5000 & 1.44386 & 8.262 & .000 & YeS \\
\hline informationalbarrier & 50 & 3.0667 & 1.26044 & 6.801 & .000 & YeS \\
\hline legalandPoliticalbarriers & 50 & 2.4000 & 1.06086 & 3.213 & .002 & YeS \\
\hline Customprocedureandlicensing. & 50 & 3.5000 & 1.30838 & 9.117 & .000 & YeS \\
\hline Technicalstandards & 50 & 4.1000 & 1.18893 & 13.942 & .000 & YeS \\
\hline anti-dumping & 50 & 3.1000 & 1.50367 & 5.873 & .000 & YeS \\
\hline Ianguagesandcustoms & 50 & 3.0167 & .96536 & 8.479 & .000 & YeS \\
\hline Culture & 50 & 2.8500 & 1.32544 & 5.201 & .000 & YeS \\
\hline Iabelingandpackagingrequirement & 50 & 4.0333 & 1.05713 & 15.192 & .000 & YeS \\
\hline Sanitaryandphytosanitary(SPS)mea & 950 & 3.9500 & 1.06445 & 14.481 & .000 & YeS \\
\hline importquotasofdestinationcountry & 50 & 2.4333 & 1.14042 & 3.215 & .002 & YeS \\
\hline Demandoftheproduct & 50 & 2.7000 & 1.19745 & 4.787 & .000 & YeS \\
\hline Competitionfromfirmsinforeignmark & 50 & 2.5833 & 1.23908 & 3.897 & .000 & YeS \\
\hline $\begin{array}{l}\text { lackofcapitaltofinanceexpansi } \\
\text { oninto foreignmarkets }\end{array}$ & 50 & 2.9667 & 1.22082 & 6.387 & .000 & YeS \\
\hline businessenvironment & 50 & 2.6000 & 1.06086 & 4.673 & .000 & Yes \\
\hline industrialpropertyrightsandcopyright & & 2.7333 & 1.27381 & 4.703 & .000 & YeS \\
\hline Corruption & 50 & 2.6167 & 1.27680 & 3.984 & .000 & YeS \\
\hline Currency Traderate & 50 & 3.2667 & 1.19131 & 8.496 & .000 & YeS \\
\hline Climaticconditionsofdestinationcou & 50 & 2.0500 & 1.01556 & .686 & .495 & No \\
\hline Transportationcostandduration & 50 & 2.7833 & 1.23634 & 5.158 & .000 & YeS \\
\hline Certification & 50 & 3.3167 & 1.26881 & 8.282 & .000 & YeS \\
\hline $\begin{array}{l}\text { Workingstructure/scheduleofthetar } \\
\text { geting country }\end{array}$ & 50 & 1.6667 & .83700 & -2.715 & .009 & YeS \\
\hline
\end{tabular}

Table-6.5 shows that Pakistani exporters have significant feelings for all the barriers except the climatic conditions of the destination country, which are regarded by the mas a Internal factor.

\subsection{Percentage analysis}

Percentageanalysishasbeendonetocheckthestrengthofeachsignificantbarrier.These barriers are divided into two parts - common barriers to export and hidden barriers. Commonbarriersarethosethatexistduetogovernmentalregulationsandpoliciesand

whichglobalorganizationssuchasWTOfindasolution, andtheycansolvethroughthe agreements. Hiddenbarriersarethosethatexistnaturally,andgovernmentbodiescannot really make solutions on them, but these hidden barriers can affect export negatively. 


\subsection{CommonBarriers}

Table6.6..Percentageanalysisof Pakistani exporters'perceptionofcommonbarriers

\begin{tabular}{|l|l|l|l|l|l|l|}
\hline No. & Commonbarriers & $\begin{array}{l}\text { Notandissu } \\
\text { e atall(1) }\end{array}$ & $\begin{array}{l}\text { Nobarrier } \\
(2)\end{array}$ & $\begin{array}{l}\text { Notseenas } \\
\text { barrier(3) }\end{array}$ & & $\begin{array}{l}\text { barrier(4) } \\
\text { barrier(5) }\end{array}$ \\
\hline 1. & Tariff & $5 \%$ & $37 \%$ & $20 \%$ & $23 \%$ & $15 \%$ \\
\hline 2. & $\begin{array}{l}\text { Governmentalregulatio } \\
\text { ns }\end{array}$ & $10 \%$ & $15 \%$ & $13 \%$ & $42 \%$ & $20 \%$ \\
\hline 3. & $\begin{array}{l}\text { Customsprocedurean } \\
\text { d }\end{array}$ & $7 \%$ & $22 \%$ & $17 \%$ & $25 \%$ & $30 \%$ \\
\hline 4. & Anti-dumping & $17 \%$ & $25 \%$ & $12 \%$ & $20 \%$ & $27 \%$ \\
\hline 5. & $\begin{array}{l}\text { Technicalstandards } \\
\text { andhealthregulations }\end{array}$ & $5 \%$ & $10 \%$ & $8 \%$ & $30 \%$ & $47 \%$ \\
\hline 6. & $\begin{array}{l}\text { Sanitaryandphytosanita } \\
\text { ry measures }\end{array}$ & $2 \%$ & $13 \%$ & $8 \%$ & $42 \%$ & $35 \%$ \\
\hline 7. & $\begin{array}{l}\text { importquotaof } \\
\text { destinationcountr } \\
\mathrm{v}\end{array}$ & $23 \%$ & $33 \%$ & $25 \%$ & $13 \%$ & $5 \%$ \\
\hline 8. & $\begin{array}{l}\text { industrialpropertyrights } \\
\text { andcopyrights }\end{array}$ & $20 \%$ & $27 \%$ & $23 \%$ & $20 \%$ & $10 \%$ \\
\hline 9. & Certification & $10 \%$ & $20 \%$ & $17 \%$ & $35 \%$ & $18 \%$ \\
\hline 10. & \begin{tabular}{l} 
Priceofthecommodity \\
\hline
\end{tabular} & $20 \%$ & $27 \%$ & $33 \%$ & $15 \%$ & $5 \%$ \\
\hline
\end{tabular}

Porters'perceptionofcommonbarrier. Table 3 and Fig. 2 show that respondents regard governmental regulations, customs procedure and licensing, technical standards and health regulations, sanitary and phytosanitarymeasuresandcertificationasthemajorbarrierstoexport.Theanti-dumping andtariffbarrierarenotthemajorbarriersbuttendstobethemajorones.Thetariffbarrier maybelowduetoseveralroundsofGATTandWTo.Theimportquotaofthedestination countryandthePriceofthecommodityarenotregardedasbarriers, either.

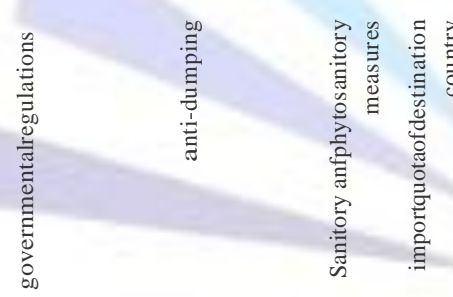




\subsection{Hiddenbarriers}

\section{7}

Table6.7.PercentageanalysisofPakistaniexporters'perceptionofhiddenbarriers

\begin{tabular}{|c|c|c|c|c|c|c|}
\hline No & Hiddenbarriers & $\begin{array}{l}\text { Notanissue } \\
\text { atall(1) }\end{array}$ & $\begin{array}{l}\text { Nobarrier } \\
\text { (2) }\end{array}$ & $\begin{array}{l}\text { Notseenas } \\
\text { a barrier(3) }\end{array}$ & $\begin{array}{l}\text { barrier } \\
\text { (4) }\end{array}$ & $\begin{array}{l}\text { Veryserious } \\
\text { barrier(5) }\end{array}$ \\
\hline 1. & Marketaccessproblem & $13 \%$ & $17 \%$ & $10 \%$ & $27 \%$ & $28 \%$ \\
\hline 2. & informationalbarrier & $13 \%$ & $23 \%$ & $18 \%$ & $33 \%$ & $17 \%$ \\
\hline 3. & Iegalandpolitical barriers & $25 \%$ & $27 \%$ & $33 \%$ & $13 \%$ & $2 \%$ \\
\hline 4. & languagesandcustoms & $5 \%$ & $23 \%$ & $43 \%$ & $22 \%$ & $7 \%$ \\
\hline 5. & Culture & $17 \%$ & $32 \%$ & $15 \%$ & $23 \%$ & $13 \%$ \\
\hline 6. & Demandoftheproduct & $20 \%$ & $22 \%$ & $35 \%$ & $15 \%$ & $8 \%$ \\
\hline 7. & $\begin{array}{l}\text { Competitionfromthefirmsinth } \\
\text { e foreignmarket }\end{array}$ & $25 \%$ & $23 \%$ & $27 \%$ & $18 \%$ & $7 \%$ \\
\hline 8. & $\begin{array}{l}\text { lackofcapitaltofinance } \\
\text { expansionintoforeignmark } \\
\text { et }\end{array}$ & $15 \%$ & $18 \%$ & $33 \%$ & $22 \%$ & $12 \%$ \\
\hline 9. & $\begin{array}{l}\text { businessenvironment } \\
\text { ofthe targetingcountry }\end{array}$ & $18 \%$ & $25 \%$ & $38 \%$ & $15 \%$ & $3 \%$ \\
\hline 10. & Corruption & $23 \%$ & $30 \%$ & $15 \%$ & $25 \%$ & $7 \%$ \\
\hline 11. & Currency Traderate & $8 \%$ & $20 \%$ & $23 \%$ & $33 \%$ & $15 \%$ \\
\hline 13. & $\begin{array}{l}\text { Transportationcostanddurat } \\
\text { on }\end{array}$ & $17 \%$ & $30 \%$ & & $25 \%$ & $8 \%$ \\
\hline 14. & $\begin{array}{l}\text { Workingstructure/schedule } \\
\text { of thetargetingcountry }\end{array}$ & $55 \%$ & $25 \%$ & $18 \%$ & $2 \%$ & $0 \%$ \\
\hline 15. & $\begin{array}{l}\text { labelingandpackagi } \\
\text { ng regulations }\end{array}$ & & $7 \%$ & $13 \%$ & $37 \%$ & $40 \%$ \\
\hline
\end{tabular}

Table6.7. and Fig. 3 show that the respondents regard the market access problems and labelingandpackagingasthemajorbarrierstoexport.Althoughnotthemajorbarriers butculturalone,thecurrencyTraderateandinformationalbarriertendtobethemajor barrierstoexport.TheLegalandPoliticalbarriers, LanguagesandCustoms, demandof theproduct,workingstructure/scheduleofthetargetingcountry,businessenvironment are not regarded as barriers to export.

When exporters were asked about the other barriers they face than the above- mentioned common and hidden barriers, most of the respondents said that coordination is another barrier they face mostly 


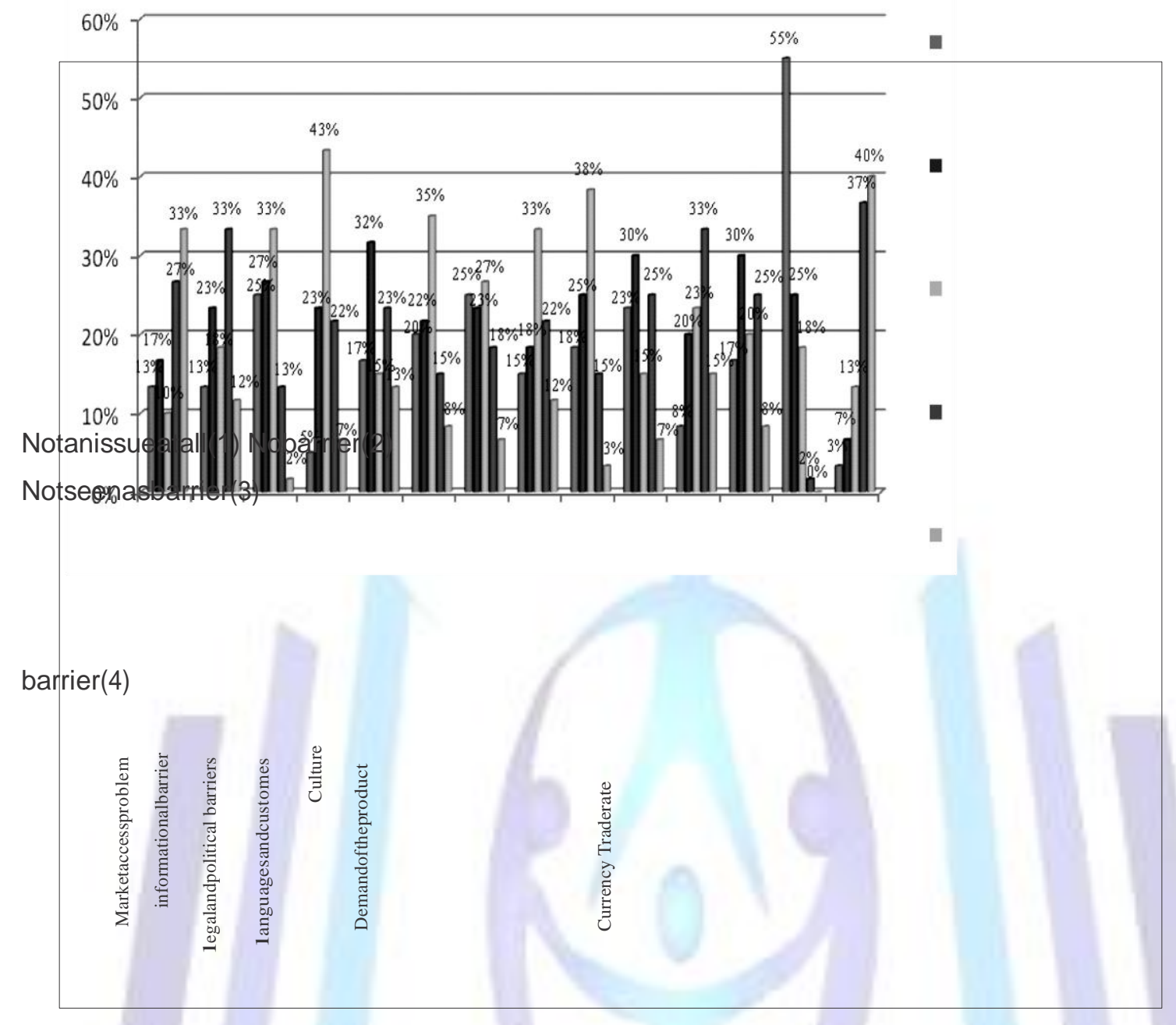

Fig3.PercentageanalysisofPakistaniexporters'perceptionofhiddenbarrier

\subsection{Exporters'attitudeafterdecreasingthestrengthofbarriers}

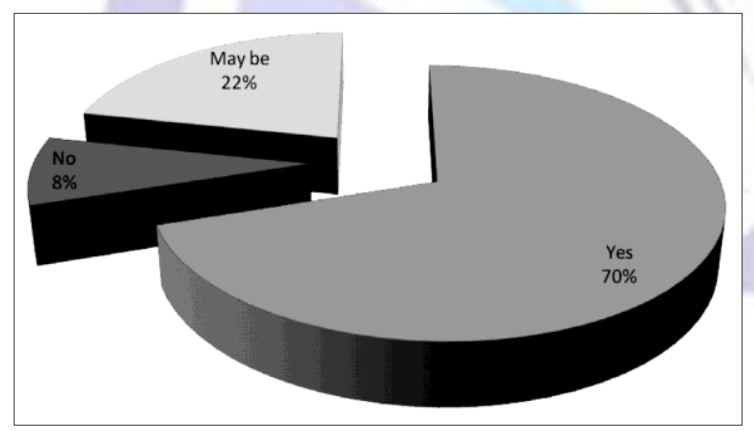

Fig. 6.4.Exporters'opiniononexportafterdecreasingthestrengthofbarriersExporters have been askedif they are ready toexport moretothe INDIAafter these barrierswillbeless, and70\% of theexporterssaidyes, $22 \%$ saidmaybe, and $8 \%$ said no.Thus, exportersarepositiveregardingexporttotheINDIA.India'sexporttotheINDIAcan be increased if these barriers get less or are removed.

\section{Conclusions}

This research focused on the Barrier of Pak-India trade relation on SAFTA by using Model Pakistan's volume of imports rises by 1.23 percent while its volume of exports falls slightly by 0.4 percent reflecting the fact that the pressure to increase imports is stronger than the increase in demand for Pakistan's exports by unilateral liberalization. However, as a result of the composite export price increase by 2.1 percent, Pakistan's experiences a small improvement in the terms-of-trade of 1.5 
percent and the real GDP by 0.9 percent. The welfare gains or losses for other regions are quite varied under this simulation. However, since Pakistanis impact on unilateral reduction of import tariffs to 15 percent will not affect other region's real GDP or terms-of-trade significantly. Althoughnotthemajorbarriers butculturalone,thecurrencyTraderateandinformationalbarriertendtobethemajor barrierstoexport.TheLegalandPoliticalbarriers, LanguagesandCustoms, demandof theproduct,workingstructure/scheduleofthetargetingcountry,businessenvironment are not regarded as barriers to export.

\section{References}

1. Ahmed, S., S. Kelegama, and E. Ghani (2010). Promoting Economic Cooperation in SouthAsia: Beyond SAFTA. Sage Publications, New Delhi.

2. Bandara, J. S. and Yu, W. (2003). "How Desirable is the South Asian Free Trade Area? A Quantitative Economic Assessment." In Greenaway, DS. (ed.) World Economy: GlobalTrade Policy 2003 , Oxford, U.K.: Blackwell Publishing

3. Baysan, T., Panagariya, A and Pitigala, N. (2006). "Preferential Trading In South Asia", World Bank Policy Research Working Paper 3813, January 2006

4. Bhagwati, J., and Panagariya, A. (1996). "The Theory of Preferential Trade Agreements: Historical Evolution and Current Trends." American Economic Review. 86(2): 82- 87.

5. Coulibaly, S. (2004). "On the Assessment of Trade Creation and Trade Diversion Effects of Developing RTAs," Paper Presented at the Annual Meeting 2005 of the Swiss Society of Economics and Statistics on Resource Economics, Technology, and Sustainable Development. (available at http://www. wif.ethz.ch/resec/sgvs/078.pdf)

5. CUTS, (2012), "Cost of Economic Non- Cooperation to Consumers in South Asia", Working Paper, Consumer Utility Trust Society, Jaipur, India.

6. CUTS, (1996). "Cost of Non- Cooperation to Consumers in the SAARC Countries: An Illustrative Study", Working Paper, Consumer Utility Trust Society, Jaipur, India.

7. Das, S. and Pohit, S. (2006), "Quantifying the Transport, Regulatory and Other Costs of Indian Overland Exports to Bangladesh," The World Economy, Vol. 29, No. 9, 1227- 1242.

8. De, P. and Raihan, S. (2011), "Unlocking India-Bangladesh Trade Potential: Emerging Issues and the Way Forward", paper prepared for the World Bank.

9. DeRosa, D. A. and Govindan, K. (1995). "Agriculture, Trade, and Regionalism in South Asia." Food, Agriculture, and the Environment Discussion Paper 7, Washington, D.C.: International Food Policy Research Institute.

10. Dimaranan, B.V. and R.A. McDougall. Global Trade, Assistance, and Production: The GTAP 5 Data Base, Center for Global Trade Analysis, Purdue University. 2002.

11. Feridhanusetyawan, T. 2005. Preferential Trade Agreements in the Asia- Pacific Region. International Monetary Fund Working Paper 05149. Washington, DC: International Monetary Fund.

12. Ju,JiandongandKalaKrishna.(1998).FirmBehaviorandMarketAccessinaFreeTradeAreawithRulesofOrigin. NBER working Paper, No. 6857.

13. Panagariya,A. (1994).East Asia and theNew Regionalism.World Economy, 17:6, 817-39.

14.

Panagariya,A.(1995).RethinkingtheNewRegionalism',PaperPresentedattheUNDPWorldBankTradeExpansion Conference,January,WorldBank,WashingtonDC.

15.

Panagariya,A.(2000).PreferentialTradeLiberalization:TheTraditionalTheoryandNewDevelopments. JournalofEc onomic Literature,38, June 287-331.

16. Purcell, Garry. (2004a). Analyzing the Economic Welfare Consequences of A Fare Trade Agreement: Partial EquilibriumMethodsforIndustry LevelStudies, Manuscript Presented atWorld bankDhaka Office.

17. Purcell,Garry.(2004b).AnIndia-

BangladeshFreeTradeAgreement?SomePotentialEconomicCostsandbenefits, presented during 
theworkshop heldatWorldBank, Islamabad Office.

18. Summers,L.(1991).RegionalismandtheWorldTradingSystems,FederalReserveBankofKansasCity,Polic 19. GEP, (1998). "The Report of the SAARC Group of Eminent Persons", SAARC Secretariat, Kathmandu. 